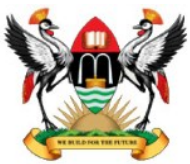

East African School of

Higher Education Studies \& Development
Makerere Journal of Higher Education

ISSN: $1816-6822 ; 9$ (1) (2017) $113-132$

DOI: http://dx.doi.org/10.4314/majohe.v9i1.10

(C) The Author(s) 2017

Reprints \& permission: EASHESD

http://ajol.info/majohe

\title{
Adult and Lifelong Learning: Implications for Sustainable Development and Employment Creation
}

\author{
Ojo-Ajibare J. O. ${ }^{1}$ \\ ${ }^{1}$ Department of Lifelong and Continuing Education, University of Lagos.
}

\begin{abstract}
This study was carried out to ascertain the extent to which lifelong learning and continuing education enhanced workers' professional competence; sustainable development; and employment creation. It adopted a descriptive design. A purposive, multistage, random sampling procedure was used to select 200 (116 males and 84 females) students of the Distance Learning Institute (DLI), University of Lagos. Data was collected using a questionnaire and an interview schedule. The results showed that majority of the respondents affirmed that lifelong learning and continuing education enhanced both the intellectual growth and industrial intelligence of employed workers. Some 96.5 percent of the respondents asserted that the possession of a university degree certificate is desirable for sub-degree holders or holders of associate degrees to gain competitive advantage in access to social and economic resource including employment creation. It is recommended that the National Universities Commission (NUC) urges institutions providing continuing education programmes to complete its accreditation processes in order to establish excellent academic standards.
\end{abstract}

Keywords: Lifelong learning; ODL; Quality assurance.

\section{$1 \quad$ Introduction}

Besides individuals initial secondary school education to secure entry-level (first) job or employment in the labour market, each person especially the adult desire lifelong learning or continuing education in one hand to stimulate or enhance intelligence, ingenuity, cleverness, growth potentials, creative and productive capacity for sustainable development (continuous improvement in learning) job and employment creation. More importantly, knowledge explosion in the re-design of jobs integrated with robotics which has hitherto replaced human labour coupled with emerging trends in the application of 
industrial technology at the workplace to manufacturing processes make lifelong learning and continuing education or learning by discovery (heuristic education or problem-solving education) imperative for adults to continue in learning and consistently renewing knowledge, skills and attitudes throughout lifetime.

Whereas lifelong learning refers to pattern of, regular way or orderly sequence of total lifetime learning activities and experiences while continuing education though a more complex concept provides the opportunity, willingness, willpower, stimulus, curiosity, right mental set, ability and determination to learn. Application of heuristic approach to learning is consistent with Ippoliti (2015), Obidiegwu and Ojo-Ajibare (2009) affirmation of same for stimulating the potential power or creative ability of youth and adults to learning through a variety of means which include library search, laboratory experiments and workshop practicals. It means that despite characteristic human difficulties and challenges, youth and adults are required to develop the power of self-expression, learn purposefully and usefully in a lifetime. One can gather from here and naturally too, that in human development or growth process, lifelong learning and continuing education are positioned at the disposal of both new entrants into the job market and those who are already in employment to navigate through a variety of career options and job clusters to enable individuals cope satisfyingly with present and future jobs within organizations. This explains the role of lifelong learning and continuing education in career exploration, career preparation, income earning and investment promotion. Based on this premise, continuing education is seen as the aspect of education which deals with constant verification, renewal and reconstruction of knowledge for promoting lifelong learning, investment in social and economic ventures for employment creation or regeneration.

In another sense, the need to improve human capital formation, that is, for individuals to maintain currency or professionalism in the practice of one's profession or career and remain employable make continuing education indispensable to adult lifelong learning and acquisition of requisite knowledge, skills and abilities (KSAs). Professionalism here implies that people are imbued with the behaviour, skills or qualities often demonstrated by professional experts and practitioners to promote expert knowledge, expertise or know-how of a discipline or field of endeavour. This is concerned with strict adherence to and compliance with professional ethics, oath of allegiance, loyalty and obedience taken through induction ceremonies, initiation, principles, doctrines and practice of professions as prescribed, established or bonded by law, legislation, convention and Act of parliament of professional bodies or association such as in education, accounting, law, agriculture, health professions and others. In this context, continuing education is concerned with fostering the acquisition, conservation, refinement, distribution and 
dissemination of knowledge among youth and adults for a lifetime. The learning experience (experiential knowledge) is systematic, sequential, planned, organized, coordinated, unhindered while it brightens and expands the scope of knowledge, thus leading individuals from lower to higher levels of educational attainment.

Perhaps, it is for this reason that many institutions established Open and Distance Learning Education Programmes while others changed the nomenclature of academic programmes to reflect the global trend of education and cater or provide for the learning needs of workers, that is enable workers enrol in post-secondary school learning activities and programmes for personal enrichment and employment creation. Whereas in America, Cornell University and University of Wisconsin, Madison through their respective universitybased continuing education courses for lifelong learning established agricultural extension service programmes to train farmers on modern methods and techniques of farming. Some scholars (Rogers, 2005; Schugurensky, 1907) argued succinctly that:

Old and dead-end skills which are obsolete for today's labour market needs must give way to new knowledge... farmers need to attend seminars or retrain on new farming methods.

While in England, in addition to providing career enhancement and Open University degree to various categories of workers in education, law, accounting, business, health-care and related professions, the University of London and the University of Leeds through university-based training and development education offered training and development programmes to employees of agricultural and allied professions at Sheffield Research Institute and Corby Steel Works on the use of the by-products of coal and oil for the production of fertilizer and animal fees. The role of continuing education in lending intelligibility to lifelong learning, career advancement and development as well as job mobility through open and distance learning programmes was described in this way:

...that about 30.6 percent of holders of sub-degree qualification needed extra credit hours in open and distance learning programmes to qualify or fit them for present and future jobs (Dench, Perryman and Giles, 1998; Storey and Sisson, 1993).

It can be deduced from the foregoing discussion that in twofold perspectives, continuing education combines or links theory with practice (i.e. learning runs concurrently or simultaneously with working or employment creation). Again, it can be inferred from the information given above that continuing education was planned by institutions as evening, part-time and weekend programme to accommodate the schedule of working students. Learning takes place outside 
the working hours usually as evening programmes. It is adult education in the sense that the clientele are youth and adults who of necessity must pass through the rigour of career exploration, professionalism, education and training, combine work with study as well as apply knowledge to the production of goods and services. It concerns involvement in continuous learning from lower to higher level of educational attainment from simple to complex form of knowledge to ascend the peak of the career ladder. Thus, continuing education becomes an inescapable or inevitable process of lifelong learning for indigent impoverished and pauperized students to prolong their employment or tenure within organizations. In other words, individuals with this dual identity benefit from both on-going learning and on-the-job experiences. The learning experience is put to use immediately, it is not banking education as proposed or propagated by Illich (1976) that is, de-schooling society.

In contemporary times, available facts reveal that knowledge economy (using knowledge to generate tangible and intangible benefits or values) remains one of the most rational, pragmatic and innovative intellectual process of encouraging individuals (especially adult and workers) to acquire relevant knowledge, skills and abilities for self-development, career growth and sustainable development. This is done by advising or helping workers to invest more in continuing education through Open and Distance Learning or correspondence and online education programmes. Knowledge economy in this context depicts a labour force which is characterized by computer literacy, well-trained and skilled in handling data, developing algorithms (formulas, instructions) and simulated models. In other words, knowledge economy requires that an adult engages himself in self-directed learning activity and in some programmes of education for personal enrichment and employment creation. Knowledge economy is described simply by some scholars (Amidon, Fornica and Mercier-Laurent, 2005; Drucker, 1969) in this form:

Knowledge (knowledgeable) worker or adult works with his or her head, not hands, and produces ideas, knowledge and information.

The question arises like this naturally; why is emphasis placed on knowledge economy? Answer to this question is not farfetched however, two major reasons stand out. First, it should be noted that past financial mismanagement of the economy coupled with reduced government funding of public education culminated in rationalization of university academic programmes by both local and foreign institutions. Cutting down academic programmes which are characterized by low competitiveness, low students' enrolment and lower employment or job prospect means cost-cutting for government but a shift of the financial burden for education from government to students and their parents. In another aspect, it should be acknowledged that growing poverty and increasing inequity in the distribution of income together with ongoing 
economic crisis have inadvertently promoted some educational reforms with consequences for increased users (students) fees. In recognition of the competitiveness in the labour market and the demand by employers for educated, trained and skilled labour force, it can be inferred from the two points presented above that rationalization of academic programmes including change of nomenclature of academic programmes by institutions have placed continuing education at a strategic or vantage position to cater for the educational needs of adult (workers) and that of underserved people. Based on this highlight, this paper examined the concepts of continuing education and lifelong learning, sustainable development and employment creation.

\subsection{Conception of Continuing Education and Lifelong Learning}

In this context, continuing education is seen as an impetus or stimulus which results in increased learning activity to achieve the goals of lifelong learning. Conceptually, continuing education is a complement to lifelong learning, that is, by implication continuing education is an integral part of lifelong learning. This clarification is important to avoid some conceptual or ideological contradictions because of the interdependent application of the two concepts.

In the general body of knowledge, continuing education seems to defy a definite form or structure of definition because it is adaptable to diverse human learning needs and situations. It is rather amorphous or nebulous, that is, lacking in form or expression. Whereas some American and European scholars (Rogers, 2005; Keep and Mayhew, 1998) looked at continuing education from the perspective of Chautauqua Sunday School Literacy model with all the attributes of post-initial education, out-of-school education (education conducted outside the formal school system), remedial education, part-time school or evening-school serving certain categories of clientele. With this outlook, it seems delusive to classify or describe adult literacy or basic education and remedial education as continuing education. It could be argued that until someone undertaking remedial education programme at a level not lesser than secondary school remedy his or her deficiency and proceeds to a higher level of educational or career attainment, such learning experience may not qualify to be described as continuing education. Moving about in cyclic learning activity like in remedial education or coaching classes may also not be described as continuing education.

A critical look at this issue revealed that Egunyomi (2015) and Akinpelu (2002) distilled continuing education from a compendium of terms and ideas similar to adult education. With the reflection, these researchers argued that continuing education has common characteristics with adult education in that it is a systematic, sequential, planned and organized body of knowledge. In this prescriptive rather than descriptive approach, the word "sequential" means that 
the learning experience, materials, syllabus or curriculum, everything is arranged and presented in sequence, step by step or order of importance, illustrating different level of, and hierarchy of learning achievement and outcome. Further from this, the experts cited above contended that continuing education is both recurrent and lifelong education because continuing and recurrent education implies carrying forward the education that youth and adults received before. While it is noted that lifelong learning is a much more all-inclusive and all-embracing concept. In addition to the view presented here, it is apt for one to say that as an educational endeavour, it is recurrent education because the learning that takes place, keeps on re-occurring or appearing several times (recurring from time to time) in semester and sessions with great reflections leading to higher levels of learning difficulties and improvement of knowledge over time. Continuing education is both lifelong and inclusive education in that it covers a wide variety of disciplines and an array of practitioners in the field while the learning experience hinges on for a lifetime.

Continuing education is also interrelated with non-formal education including extra-mural studies. Both of them have common characteristics with organized lecture taking place outside of the formal school system. This mode of learning by its flexibility encourages holders of sub-degree qualifications with felt-need to register for extra credit to earn university degrees. It has also enhanced professionalization of some professions such as Institute of Chartered Accountants of Nigeria (ICAN), Chartered Institute of Bankers of Nigeria (CIBN), Association of Certified Chartered Accountants (ACCA), Institute of Chartered Secretaries of Nigeria (ICSN) and others. Practitioners in these different fields after undergoing rigorous course of study, passed prescribed qualifying examinations are certified, inducted and or licensed to carry out professional and private practice while at the same time, offering consultancy services. It is a systematic, planned and organized body of educational efforts provided by a variety of interested agencies outside of the formal school system for youth and adults in order to ascend to the top of their educational and career ladders in their lifetime. More importantly, it is an integral and necessary part of adult education which places more emphasis on postsecondary school education programmes to increase career options available to individuals. Based on the current ideas and facts obtained from both local and international institutions, it is obvious that both in form and structure, continuing education is interdependently related to adult education, a recurrent and lifelong learning as well as non-formal education.

\subsection{Sustainable Development}

Sustainable development implies the ability of a thing, system, person or idea to start from a small beginning, continue to grow in size, evolve, enlarge in scope 
or expand in dimensional area, volume and endure under difficult or painful situation for a long time without causing rupture, fracture, buckle, damage, disruption, dysfunction or impairment to existing developmental process and management structure or system. In specific terms, it also denotes the ability of a person or individual's expansion or enlargement in scope of knowledge, under-standing, wisdom, reasoning and development of intellectual capacity and continuity in learning for a life time (lifelong learning) and remains resilient to discouragement even when subjected to difficulty or stress at yield point.

It can be gathered from this background information that sustainable development is concerned with persistence, firmness and resolute or purposeful commitment to personal, social and economic development of the environment without impeding the growth of present and future generations.

However, the United Nations (1995:149-150) attempt at making further clarification states that sustainable development is concerned with the capacity to meet the needs of the present without compromising the ability of future generations to meet their own needs. It is important in this context to reiterate that the ability or effort to meet the needs of the present age should not in any form hamper, thwart, disrupt, undermine, forestall, frustrate, hinder or destroy the developmental ability or process of future generations to meet their own needs. This marks a paradigm shift from the culture of silence (Freire, 1972), complacency, waste, culture of survival instinct or the throwaway culture. It should be noted that in this era, change is inevitable and indispensable to the way of thinking and doing things whereby the old order is replaced by science and technology and vigorous pursuit and application of knowledge. In a more profound way, sustainable development places a burden of proof on individuals or group of persons alike to develop an ever-increasing propensity towards the renewing of strength, energy, knowledge, wisdom and understanding through insightful thought, scientific discoveries, and lifelong learning without weary.

The insight provided above is consistent with Lynn and Gurel-Attay (2014) and Brundtland (1987) commission identified nine elements of development which comprise education, employment and conditions of work, health, food consumption and nutrition, housing, social security, clothing, recreation and human freedom. It can be inferred from these nine components that sustainable development is associated with the educative process, that is, education especially continuing education and lifelong learning is indispensable to the development of human capital (knowledge, skills and abilities) (KSAs) for work and employment creation with man being the change-agent and clientele. As it is, sustainable development places premium on education for the development of human knowledge, intellect, skills and abilities with continuing education fostering and increasing individual's career options, job mobility and advancement to make work become more meaningful. Changes in employment 
patterns and workplace processes evolve rapidly and these changes exercise a great deal of impact on the topography of relevant knowledge and skills, and on the capacity of individuals particularly adults to participate in learning and work. All these changes put together have made continuing education essentially suited to sustained long term resource management efficiency and human capital development.

\subsection{Lifelong Learning, Continuing Education, Sustainable Development and Employment Creation}

One of the major landmarks of the industrial revolution that took place in England in the $18^{\text {th }}$ and $19^{\text {th }}$ centuries is the transition from hand (manual) production to machine production of goods and rendering of services. The import of this innovation is that one, human knowledge, skills and abilities (KSAs) need to be developed and adaptable to meet lifetime needs of industrial and technological age for educated, trained and skilled labour force. It is important too, that human energy, ingenuity, cleverness and expertise for mass production of goods, that is, produce goods and services in great and sufficient quantities and quality to meet present needs and that of the foreseeable future generations without undermining the integrity, stability and beauty of natural biotic systems. Effort to achieve this sustainable development goal agenda began with Cornell University offering university-based lifelong and continuing education to teachers in the Department of Geology to expand their foundations of knowledge and stay up-to-date, that is, keep the teachers abreast of new developments in their profession. This novel idea attracted the attention of the University of Wisconsin-Madison with the founding in 1919 the School for Social Research which was devoted to the study of adult education programmes especially agriculture and extension services. Some scholars (Robert, Jnr. 2002 $\&$ Rosen, 2012) captioned the mood of university teachers and students on the dimension of the new education system in this way that:

University teachers and students believed that the value of education had risen due to economic recession ... with lifelong and continuing education enhancing the growth rate in the number of workers registered for part-time continuing education programmes due to the opportunity available to them which enabled employed workers (working students) to combine work with personal and career development.

Further enquiry revealed that by 1976, the University of Florida had created its own division of continuing education with an initial intake of about 1,500 students, majority of who were workers. The art of training teachers on how to impart knowledge to other people especially in engineering disciplines (geology and mining) through university-based extension programmes as 
illustrated above demonstrates an important aspect of human capital development for sustainable development and employment creation.

In Europe for instance, the Universities of London and Cambridge alongside with the University of Manchester were among the pioneer institutions of learning that have consistently encouraged employment creation and sustainable development through continuing professional development education. Discernible trends suggest that many of these institutions established different forms of post-secondary school learning assistance centres located within the domain of each university's college or school of continuing education, school of continuing legal education, school of continuing medical education, community education and lifelong education to meet industrial requirements. While the broad areas in continuing professional development education of the University of London include accounting, accounting and finance, accounting with law, agricultural economics, applied education, leadership and management, demography and health, development and economics. The University of Manchester offers a range of subjects in professional continuing development education programmes in management and research skills, health and public sector management, computer science, teaching, training and distance learning programmes. Statistical release by the institution shows that about 18,500 community pharmacists benefitted from University of Manchester continuing professional development education in pharmacy. Keith (2002) described the trend in the establishment of universities' continuing professional development education programmes for adults thus:

Courses were customized to meet industrial requirements, increase career options, job mobility and reduce labour turnover among adult industrial workers (Keith, 2002).

The idea of customized courses, made-to-order, non-residential academic programmes probably informed the setting up in 1946 the Department of ExtraMural Studies and Continuing Education Unit of the University of Ibadan, Nigeria under the auspices of the Oxford University Extra-Mural Delegacy.

\subsection{Adult and Lifelong Learning in Nigeria}

It is a matter of logic, conscientiousness and insightful thought that continuing education has been used to promote lifelong learning for meeting both the educational and career advancement needs of youth and adults who combined productive work with professional development that is schooling. This view is consistent with Omolewa (1985) assertion that continuing education is a desirable extension of educational response to trends in societies' demand for education which is relevant to work and professional development. One fact that is deducible from the above is that continuing education has continually 
been used to break the cycle of repeated examination failures which restrained many youth and adults from transiting from high school to college or university. Effort by prospective candidates to obtain mandatory results to meet university admission requirements induced many of the students with deficient results to enrol in learning-assistance centres popularly referred to as coaching centres where students are prepared to write the General Certificate Examination (GCE) 'Ordinary' or 'Advanced' level papers. This is exemplified by 1948 list of provisional admission of students into extra-mural and continuing education programmes of the University of Ibadan presented by Omolewa (1985:79) as inherited from the Oxford University Extra-Mural Delegacy. As exemplified by the attendance records, about one hundred and forty-one (141 persons) students mostly workers drawn from different occupational backgrounds such as clerical work, teaching, agricultural extension services, technical works, civil service and land surveying to mention but a few were offered admission.

Although the University of Ibadan Extra-Mural Studies and Continuing education started continuing education programmes in Nigeria with the students inherited from the Oxford University Extra-Mural Delegacy, nonetheless, other private providers outside the purview of university extension classes quickly took advantage of the trend to provide remedial and continuing education programmes through correspondence, open and distance learning for the benefit of youth and adults seeking to write London University Matriculation and Intermediate degree examinations and Senior Cambridge School Certificate Examinations. These include Wolsey Hall and Rapid Results College, University of London with its registered Satellite Study Centre (Exams Success and Correspondence College) located at 10-12, Labinjo Avenue, Off Shipeolu Street, Palm Grove area of Lagos. Some of the courses offered include economics, accounting, law, banking and finance, commerce, store keeping, salesmanship and marketing, secretarial studies, public administration, industrial relations and personnel management and other disciplines.

As stated above, many private and public institutions took a clue from University of Ibadan Extra-Mural Studies and Continuing education programmes to provide post-secondary school evening classes and remedial education for the teeming youth and adults who desired remediation of examination results. Among the most prominent forerunners of these programme providers were Dotun Oyewole Continuing Education Centre, Abeokuta in Ogun State, Jubril Martins Continuing Education Centre, Surulere, Lagos, Premier College and Continuing Education Centre, Jibowu, Yaba Lagos. Others include Nigeria Peoples' High School and Continuing Education Centre, Kadara Street, Ebute-Metta Lagos, DAVOC Institute of Hotel Management and Catering Services, Ketu Lagos and Obokun General 
Certificate of Education (GCE) and Continuing Education Centre, Ilesha, Oshun State.

While these learning-assistance centres and continuing education centres lasted, teaching and learning was conducted in the evenings and part-time usually during weekends. Saturday part-time classes were always participative laboratory practical teaching and experiments in science subjects such as Physics, Chemistry, Biology and Agric. Science. The laboratory practicals were always conducted in collaboration with invited University of Lagos teachers in each subject area to enhance students' learning achievement.

Effort by government to reduce the rate of failure among high school graduates and facilitate youth and adults' admission to colleges and universities led to the establishment of higher school programmes (HSC) in schools through which students were prepared to write GCE "Advanced" level papers. Some of such schools included Federal School of Arts and Science (FSAS), Victoria Island, Lagos, Federal School of Arts and Science, Ondo in Ondo State. Others were Loyola College, Ibadan, Christ High School, Ado-Ekiti in Ekiti State, Aquinas College, Akure in Ondo State, Adeola Odutola College, Ijebu-Ode and Saint Gregory's College, Obalende, Lagos. The concentration of Nigerian evening schools, higher school programmes including some universities' extramural classes on remedial education (Genera Certificate of Examination, GCE) attests to the fact that Nigerian evening schools were not initially designed to meet the same requirements as that of their British counterparts which aimed to promote life-long learning with teaching directly related to professional development and employment creation.

\subsection{Lifelong Professional Development Programmes and Employment Creation}

It is now an acceptable fact that Nigerian evening schools including continuing education programmes of some universities have for too long been geared towards remedial education (examination) instead of enhancing life-long learning, professional development and employment creation. For instance, investigations conducted by this writer revealed that University of Ife (now Obafemi Awolowo University, Ile-Ife) recruited local secondary school tutors to teach English, Mathematics, Science, Social Science and Arts subjects to GCE and Royal Society of Arts (RSA) candidates at Oduduwa College, Ile-Ife. Similarly, University of Nigeria, Nsukka and the University of Benin conducted extra-mural studies at both Nsukka and Benin for about 500 candidates who registered for different subjects at Nsukka and Benin Extra-Mural Study Centres (Omolewa, 1981).

However, in its quest to make university education relevant to the industrial and manpower needs of the Nigerian labour market, promote intellectualism, 
lifelong learning and professional development among workers through continual training and retraining of individuals, the University of Lagos through correspondence and distance learning approaches (Correspondence and Open Studies Unit, COSU), in 1973 introduced evening classes in Law, Business Administration and Political Science. Excerpt from Omolewa (2006) report also shows that by 1983, the university expanded the scope of its academic and professional development (continuing education) programmes to conform with global trends and advances in Open Studies and Distance Learning (DSDL). The expansion of programmes led to a change of nomenclature from COSU to Correspondence and Open Studies Institute (COSIT) while Accounting, Education, Management, Banking and Finance were included in its programme of study. With the integration of its programmes in 1997 to other programmes especially professional programmes being conducted by the Council of Registered Engineers of Nigeria (COREN) and National Business and Technical Examination Board (NABTEB), COSIT was transformed to Distance Learning Institute (DLI). With this feat, University of Lagos expanded further the frontiers of knowledge, thus making university education more accessible to youth and adults in engineering and technical-related practices through pursuance of global advances and innovation in Open Studies and Distance Learning techniques.

By this feat too, the University of Lagos has couched a niche for itself in human capital development, that is, inculcating the values of education, training and the dignity of labour into people with the stock of knowledge, talents, skills, abilities, experience, intelligence, creativeness, judgment and wisdom (manpower training and development education), thus fitting individuals for industry and employment creation. Recognition of the importance of the "Human Factor" or manpower training and development education is fundamental to economic activity, competitiveness, re-construction of knowledge, training and re-training of individuals to acquire new skills for sustainable development and employment creation. Consequent upon rapidly evolving employment and workplace processes, development of human capital is essential to acquiring relevant knowledge and skills, as well as renewing the capacity of individuals young and old, men and women especially holders of sub-degree qualifications and certificates. Acceptance of Total Quality Management (TQM) with the philosophy of continuous improvement as both the global and national imperative poses formidable challenges to adults who must combine extroversion with rational thinking and analytical skills to cope convincingly with increasing complex problems of present and future job. In essence, formal programmes of education, training and professional development such as being provided by DLI, University of Lagos for individuals (adults) with COREN and NABTEB recognized qualifications and 
certificates should be viewed as investment in developing the ability of these categories of people and helping them to realize their potentials.

Recent survey conducted by this writer indicates that holders of sub-degree qualification and certificates Nigerian Certificate of Education (NCE), Ordinary National Diploma (OND) and Higher National Diploma (HND) abound in great numbers in Nigeria labour market seeking non-existent white-collar jobs. Although there is no accurate statistical data about the numerical strength of these group of persons, nonetheless, it is estimated that they numbered up to about 2.32 million on a national scale. It is also assumed that in addition to subdegree qualifications, many of these individuals possess other professional qualifications and certificates recognized by COREN and NABTEB such as NABTEB Advanced-Level Certificate in Building and Construction Management, Electrical Installation Work, Institute of Chartered Accountants of Nigeria (ICAN) and other disciplines. In pursuance of the principles and practice of lifelong and continuing education as sated inter-alia in the National Policy on Education:

...to provide in-service, on-the-job, vocational and professional training for different categories of workers and professionals in order to improve their knowledge, skills and abilities (NPE, 2004:16).

Since the possession of a university degree seems to be the benchmark for measuring educational achievement and for gaining competitive advantage in accessing economic and social benefits, it is important for these holders of subdegree qualifications and certificates to seek further education through continuing education programmes to boost self-development and employment creation. Recent investigation on youth unemployment and under-employment of graduates show that many of these individuals are widespread. While the centre of academic activities for these people is the Distance Learning Institute (DLI), some of them are located in different faculties such as Education, Engineering, Accounting and Business Administration, Environmental Studies, Works and Physical Planning and maintenance section of the university. In terms of relevance of curriculum to the needs of the students, the study adopted the University of Lagos Distance Learning Institute prospectus for Joint Admissions and Matriculation Board (JAMB) for Direct Entry Admissions of undergraduate programmes.

\subsection{Research Questions}

The study attempted to answer the following research questions;

1. Does lifelong learning (continuing education) enhance workers' (working students) intellectual ability and productive capacity for sustainable development and employment creation? 
2. Does the possession of a university degree through lifelong learning and continuing education programme enhance university graduates' competitive advantage better than that of sub-degree title holders in employment creation and access to economic and social resources?

3. Does open distance learning approach have competitive advantage over traditional methods of teaching and learning, and information dissemination in continuing education programme?

4. What are the major problems undermining efficiency and effectiveness of continuing education programmes?

\section{$2 \quad$ Methodology}

\subsection{Research Design}

The study employed the descriptive survey research design. This design is suitable for systematic collection of data in a sparsely populated and distantly located population of study. It is also suitable in determining the extent or degree of relationship between two or more intervening variables and use the results of such relationship to make valid predictions.

\subsection{Sample}

A total of 200 (116 males and 84 females) respondents of intact classes (groups) of students located in Distance Learning Institute (DLI), four faculties as well as Works and Physical Planning Department of the University of Lagos whose questionnaires were properly filled and returned constituted the sample of the study. A purposive multistage sampling procedure was adopted in selecting and administering questionnaire to the respondents used as sample for the study. Data collection on part-time students from Distance Learning Institute (DLI) and other faculties are indicated in Table 1.

Table 1: Distribution of participants

\begin{tabular}{lllll}
\hline Programme & \multicolumn{5}{c}{ Count } \\
\hline Data Collection Centres (Faculties) & Male & Female & Total & $\%$ \\
Distance Learning Institute (DLI) & 73 & 60 & 133 & 66.5 \\
Business Administration & 12 & 05 & 17 & 8.5 \\
Education & 21 & 10 & 31 & 15.5 \\
Engineering & 3 & 2 & 5 & 2.5 \\
Environmental Studies & 3 & 1 & 4 & 2.0 \\
Works and Planning & 4 & 6 & 10 & 5.0 \\
Total & 116 & 84 & 200 & $100 \%$ \\
\hline
\end{tabular}




\subsection{Instrumentation}

Questionnaire and interview schedules were the primary research instruments used in collecting data for this study. The questionnaire was a thirty-six (36) item instrument adapted from COREN, NABTEB and Nigerian Institute of Bankers (NIB) integrated curriculum. It was tagged Lifelong Learning, Sustainable Development and Employment Creation Assessment Scale (LLSDECAS). It was a reflection of the social, economic, educational and cultural conditions of the study environment (DLI, University of Lagos) using lifelong learning and continuing education to predict employed workers' behaviour modification, social, economic, cultural and intellectual development.

The instrument was divided into two sections: "A" and "B". Section A focused on demographic variables (age, sex, initial educational and professional qualifications, occupation or career, present employment, social and economic status of parents) and of the respondents. While Section B was a twenty-two (22) item instrument (Social, Economic and Self-Development Assessment Reference Scale (SESDARS) used to gather information on various aspects of DLI, COREN, NABTEB and NIB integrated curriculum. The instrument was also used to gather data on critical areas such as acquisition and application of logic and imaginative thinking, analytical and problem-solving skills as well as research skills. The researcher adopted four point Likert rating scale in designing the questionnaire. The numerical values of the descriptor performance ranged from "excellence" through "poor" and weighted as follows: Excellent $=4$, Good $=3$, Average $=2$ and Poor $=1$.

\subsection{Interview Schedule}

The questionnaire was supplemented with interview schedule. The interview schedule was based on the premise that one of the most sensitive, reliable and plausible methods of feeling the pulse of individuals to obtain information pertinent to human activities in the natural setting such as issue that concerned employed workers' involvement in continuing education and the development of intellectual ability as well as productive capacity for sustainable development and employment creation is to let the participants or respondents assess themselves by having a face-to-face dialogue with them on: relevance of curriculum to academic discipline, industrial intelligence and needs of the labour market, ability of workers (working students) to combine work with education that is, workers' ability to adopt coping and adaptive strategies (trainee readiness, creativity, resourcefulness, industry, persistence, perseverance and perspiration) to cope with the rigours of work and schooling. At the same time, imbibe good study habit, turning in assignments and term 
papers, writing examinations, plan independent study, conduct library search and research work. Others include availability of teaching equipment and resources such as lectures, teaching methods and techniques and use of laboratory. This was validated after which Kuder-Richardson formula $2_{1}\left(\mathrm{Kr}_{21}\right)$ was used to test for it reliability. It yielded a reliability co-efficient of 0.78 .

\subsection{Data Collection}

Questionnaires and interview as the primary instruments of data collection were administered directly on the respondents by the researcher supported by four research assistants.

Questionnaires were used to collect information from continuing education tutors, coordinators, facilitators, curriculum developers, examination officers and programme monitoring officers in each faculty and Distance Learning Institute. Interview and other self-report measures (projective techniques and self-disclosure were used extensively to gather information about respondents' personality traits such as self-esteem image, mental and emotional ability, readiness and willingness to learn, self-determination, willingness to accept responsibility, values, interests and needs. Reports on these measures were largely obtained from respondents during interactive sessions, group discussions, in-class and recreation centres and playing grounds. In all, 116 (58\%) male and 84 (42\%) female participants were interviewed.

\subsection{Data Analysis}

The data collected for the study were analysed using descriptive statistics such as frequency counts and percentages.

\section{$3 \quad$ Findings and Discussion}

The responses of respondents to research question 1, about 187(93.5\%) of the students concurred that lifelong learning and continuing education enhanced both the intellectual growth and productive capacity of employed workers (students) for sustainable development and employment creation. While 9(4.5\%) asserted that lifelong learning and continuing education improved general intelligence and management skills of employed workers.

On research question 2, the results show that some 193(96.5\%) of the respondents admitted that the possession of a university degree is desirable for persons with sub-degree qualifications to gain competitive advantage in access to economic and social resources as well as employment opportunities. At the same time, about 7(3.5\%) affirmed that new technology and cybernation have 
also increased the demand on lifelong learning and continuing education for the enhancement of employed workers' professional and self-development.

Some $184(92 \%)$ of the respondents agreed that open distance learning is amenable to a variety of uses and application in teaching and learning, and information dissemination in that it promotes rational and reflective thinking and development of problem-solving skills. Similarly, another group of about $13(6.5 \%)$ of the respondents argued that open distance learning facilitates generation of new ideas, transfer of learning, feedback and knowledge of results, retention, discovery learning or learning by insight and improved task performance.

Some 191(95.5\%) of the respondents confirmed that the recruitment of unqualified tutors, facilitators and instructors teaching at learning-assistance or continuing education centres is highest and most noticeable among the problems plaguing efficiency and effectiveness of continuing education programmes. This group of respondents also attributed high rates of failure among students and inefficient programmes' evaluation to instructors' poor teaching styles and technique, and overcrowded lecture halls and classroom. About 9(4.5\%) of the respondents ascribed poor learning achievement in continuing education programmes to inadequate amenities and infrastructural facilities characterized by dilapidated buildings with falling-off roofs, doors and window sills and sashes.

The results of this study show that there is congruence between intellectual growth, higher or increased productive capacity and lifelong learning and continuing education. That is, the application of new knowledge (new ideas, renewed mental ability, imaginative thinking, analytical skills, creative ability and competence by employed workers to the production of goods and services) is a function of continual or continuous learning and improvement of knowledge. This is consistent with the results that 95.5 percent of the respondents affirmed that lifelong learning and continuing education facilitated intellectual growth and productive capacity. Again, the result is amply supported by Kalineman (2003) that individuals especially persons with associate degree or sub-degree should exercise the willingness, interest and problem-solving attitude towards the development of a learning culture evidenced by increased number of employed workers undertaking further education. Such individuals should also apply position analysis questionnaire technique to consistently assess personal development for continuous improvement. Thus, it can be inferred from the results that lifelong learning and continuing education lent intelligibility to both intellectual growth and productive capacity of employed workers for sustainable development, investment promotion and employment creation.

One of the highlights of this study is the fact that some 96.5 percent of the respondents acknowledged that the possession of a university degree by sub- 
degree holders (NCE, OND, HND) and other professional qualifications and certificates recognized by COREN and NABTEB) is beneficial to gaining competitive advantage in access to social and economic resources including employment opportunities. This point is supported by Oke (2017) and Becker (1993) assertions that the "human factor" that is, the stock of knowledge is fundamental to economic activity, competitiveness and prosperity. The point being emphasized here is that the development of human knowledge, mental ability, skills and understanding is essential or critical to accepting new ideas, openness to innovation and inventions to break new grounds and move forward. Emergent discoveries in science and technology together with the application of industrial technology to the production of goods especially the use of robotics in the production of knock-down-components, and services including cybernetics have made lifelong learning and continuing education indispensable to employed workers (adults) professional and self-development. In short, lifelong learning and continuing education is not only to enable employed workers do their present and future jobs within the organization, it is the key to unlock the doors of career options and advancement as well as job mobility.

This result revealed that open and distance learning offers unique and great advantages over other methods of teaching and learning, and information dissemination. In terms of application, about 92 percent of the respondents that participated in this study agreed that this method is flexible to use and unique in information and resource sharing. This fact is also corroborated by the findings of some scholars (Oke, 2017; Storey \& Sission, 1993) that open and distance learning is unique at allowing many students to be connected to the learning centre sharing information and resources at different places or locations and at the same time without impeding the source of knowledge. It is innovative in the provision of wider training and development opportunities for employed adults. It promotes personal improvement and career enhancement ranging from Open University degree to funding assistance in professional development.

The results show further that recruitment of unqualified tutors and facilitators has added other debilitating effects which undermined teaching and learning. According to most $(95.5 \%)$ of the students, ineffectiveness of teachers' teaching styles and techniques is exacerbated by uncontrollable class-sizes, poorly ventilated and overcrowded lecture halls, obsolete equipment, and tools overburdened with usage. Similarly, some 4.5 percent of the respondents adduced students' poor performance to inadequate amenities and inefficient programmes' evaluation procedures which required constant review.

\section{Conclusion and Recommendations}

Lifelong learning and continuing education is now recognized as an essential human need because of increased globalization of economic activities, growing 
competition among industrialized and industrializing nations of the world for educated and skilled manpower in the labour market. The workplace and employment patterns evolve much more rapidly, therefore, with increasing change in technological advancement, lifelong learning and continuing education is required to increase the general intelligence of larger numbers of young workers between the teenage years and early adulthood who left school to enter employment, thus lead them to better and intelligent citizenship. Lifelong and continuing education is also required to increase workers' industrial intelligence and skills, thereby leading to advancement or preparation in another line of work, that is career option, job mobility and reduction in labour turnover.

Empirical evidence supports the fact that lifelong learning and continuing education shall continue to enhance employed workers' self-development and professional competence, therefore, the National Universities Commission (NUC) should ensure compliance of non-university-based providers of continuing education programmes with NUC's programmes accreditation processes.

State Ministries of Education and the Nigerian Education Research and Development Council (NERDC) should also ensure compliance of proprietors and coordinators of learning-assistance (continuing education) centres with registration procedures, separate remedial programmes from continuing education programmes to set and enforce standard.

\section{References}

Akinpelu, J. A. (2002). Philosophy and adult education. Ibadan: StirlingHorden Publishers (Nigeria) Ltd.

Amidon, D. M., Formica, P. \& Mercier-Laurent, E., (Eds.) (2005). Knowledge economics: Principles, practices and policies. Tartu: Tartu University Press.

Becker, G. (1993). Human capital: A theoretical and empirical analysis with special reference to education. Chicago: The University of Chicago Press.

Brundtland Commission (1987). Report of the World Commission on "Environment and Development". New York, 12017: United Nations Department of Public Information.

Dench, S., Perryman, S. \& Giles, L. (1998). Employment perception of key skills. Institute of Employment Studies (IES), Report 349. Sussex: Institute of Employment Studies.

Drucker, P. (1969). The age of discontinuity: Guidelines to our changing society. New York: Harper and Row. 
Egunyomi, D. A. (2015). Balancing life equation with continuing education. Inaugural Lecture. Ibadan: Ibadan University Press.

Illich, I. (1976). Deschooling society in Cassell \& Macmillan, C. (Eds). London: Cassell \& Collier Macmillan Publishers Ltd.

Ippoliti, E. (2015). Heuristic reasoning: Studies in applied philosophy, epistemology and rational ethics. Geneva: Springer International Publishing Corporation.

Keep, E., \& Mayhew, K. (1988). Was Ratner right? Product market and competitive strategies and their links with skills and knowledge. Employment Policy Institute Report, 12(3), 1-12.

Keith, S. (2002). What is the "knowledge economy?" Knowledge intensity and distributed knowledge bases. New York: United Nations University.

Lynn, R. K., \& Gurel-Attay, E. (2014). Communicating sustainability for the green economy. New York: Sharpee M. E. Publishing Inc.

Obidiegwu, U. J. \& Ojo-Ajibare, J. O. (2009). Bloom's mastery learning theory: Implications for adult education. The Nigerian Journal of Research and Production, 15(1), 208-217.

Oke, G. G. (2017). "Work for All: New frontiers in vocational education and training. Inaugural Lecture. University of Lagos, Akoka - Yaba: University of Lagos Press.

Omolewa, M. A. (1981). The status and problems of remedial education in West Africa. Ibadan: University of Ibadan Press.

Omolewa, M. A. (1985). Adult education practice in Nigeria. Ibadan: Evans Brothers (Nigeria Publishers) Limited.

Omolewa, M. A. (2006). Cross-over unto the other side: The mission of adult education. Ibadan: Spectrum Books Limited.

Robert, E. L., Jnr. (2002). Lectures on economic growth. Cambridge, Harvard: Harvard University Press.

Rogers, A. (2005). Non-formal education: Flexible schooling or participatory education? New York: Springer.

Rosen, W. (2012). The most powerful idea in the world: A storey of steam, industry and invention. Chicago: University of Chicago Press.

Schugurensky, D. (1907). The Wisconsin idea, bring the university to the community, selected moments of the $20^{\text {th }}$ century. The Ontario Institute for Studies in Education of the University of Toronto. Retrieved 2009-03-01.

Storey, J. \& Sission, K. (1993). Managing human resources and industrial relations. Buckingham: Open University Press.

United Nations (1995). United Nations environmental programme on sustainable development. New York, 10017: United Nations Development of Public Information. 